\title{
MORPHOLOGY, SEDIMENTOLOGY AND ORIGIN OF AN ANOMALOUS CUT-OFF ALONG THE PRAVARA RIVER, DECCAN TRAP REGION, INDIA
}

\author{
VEENA U. JOSHI
}

Department of Geography, Savitribai Phule Pune University

(Formerly University of Pune)

*Email: veenaujoshi@gmail.com

Received 20 November 2020, accepted in revised form 14 April 2021

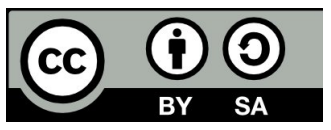

\begin{abstract}
River meanders have always been an intriguing subject in fluvial geomorphology because of their ubiquity, dynamism, remarkable forms and practical consequences of their movement. Sometimes a relatively straight channel flowing over bedrock may develop a lone meander bend cut-off which is very out of the place from the surrounding area. The occurrence of a sudden bend along a river may not be a meandering bend but may be manifestation of sudden change in the river dynamism due to many reasons, such as, lithology, change in rainfall regime, tectonics etc. The formation of such features highlights the behavior of river in the past. One such striking feature has been observed along the River Pravara in the Deccan Trap Region, Maharashtra, India. Rivers in Deccan Trap Region do not meander and form cut-offs by rule. It is rocky country where rivers flow in deeply incised bedrock. Hence, the observed feature displays a striking anomaly in this region. Hence, an attempt has been made in the present paper to evaluate the mode of formation of this single cut-off along this channel. Morphological and sedimentological data were generated and analyzed for the channel loop and the link channel to understand the competence of the river in the past and present which were directly or indirectly responsible for the development of this channel anomaly in this reach. Based on the results of the analysis and intensive field observations, it has been inferred that this is a classic example of natural morphological adjustment of a river when a set of events occurred, first retardation of vertical erosion encountering bedrock followed by series of floods to induce the channel to divert from the original path to resume the present course. Presence of a tributary further aided to the process of the loop development. The study can provide additional knowledge to the studies involving anomalous channel cut-offs at any part of the world.
\end{abstract}

Keywords: Deccan Trap Region, meander, channel anomaly, cut-off, competence, morphological adjustment

\section{Introduction}

River meanders have been a subject of great interest in fluvial geomorphology because of their remarkable forms, dynamism, ubiquity, and practical consequences of their movement (Hook 2003). Meandering channels are found on bedrocks, usually of incised character, termed valley meanders or can be alluvial river meanders normally associated with active floodplains. Sudden obstructions in a channel, the earth's rotation and excess of energy and loads have been cited as basic causes of stream meandering. Meandering patterns change over time and bends migrate. Although a great deal is known about the behavior of meandering streams and about their statistical properties, it is still not possible to define the ultimate cause of meandering. (Miall, 1977). Sometimes river 
flowing through a straight course develops a sudden bend along its path but we may not call that as a meandering bend because such bends may not be formed due to the normal meandering mechanism. The term "Meander" is technically reserved for the rather systematic curves developed by the action of river itself and appropriate to its habit of flow. Sometimes a reach of a channel may experience unusual erosion, downcutting of the channel bed, aggradations, change of channel pattern or any disequilibrium, which is known as channel anomaly. Because of such unusual behavior of channel, the natural combination of the river dimensions and characters also change, such as, width, gradient, pool and riffle sequence, length, radius, amplitude of curves and meanders and hydraulic roughness. The change in these characteristics results in the formation of unusual features displaying different characters than that of the normal features, known as anomalous feature. A channel can be diverted from its normal path if it encounters a dyke, a ridge or any obstruction, which is known as channel diversion. The older abandoned path is subsequently filled with sediments and become a palaeochannel. So, the occurrence of a sudden bend along a river may not be a meandering bend but it may be a manifestation of sudden change in the river dynamism due to reasons like lithology, change in rainfall regime, tectonics etc. Sometimes a relatively straight channel flowing over bedrock may develop a lone cut-off bend which is very out of the place from the surrounding area. The formation of such features highlights the behavior of river in the past. One such striking feature has been observed along the River Pravara in the Deccan Trap Region, Maharashtra, India. Hence the study has been designed to understand morphology, sedimentology and the origin of this anomalous feature found along the bedrock reach of this river in Maharashtra. Though this is a case study, the finding will be useful to understand river dynamics in general.

Owing to the ubiquity and dynamism, channel systems have been the subject of numerous investigations in fluvial geomorphology for over half a century. It is beyond the scope of this paper to review all the papers in this theme. Only a few, that has direct relevance to the present paper has been outlined here.

Davis (1913) in his article 'Meandering Valleys and Underfit Rivers' explained the basic mechanism of formation of valleys and concepts and features related to the meandering valleys. Leopold and Wolman, (1957) studied channel pattern and river morphology. Dury, (1960) has shown convincingly that meander systems fall into quite distinctsystems, when their wavelengths are related to their drainage areas. Schumm and Khan (1972) and Miall (1977) have classified river patterns based on flow related parameters. Van den Berg (1995) introduced a method, which enables prediction of the equilibrium conditions for the occurrence of braided and sinuosity meandering rivers in unconfined alluvial floodplain. The result of experiments that simulated the formation of well-defined, highly sinuous meanders in a small flume using light, fine grained material was presented by Smith (1998). Levin and Brewer (2001) proposed distinction between meandering and braided river channel pattern, on the basis of bankfull specific stream power and bed material size. Hooke (2003) examined types of meander behavior ranging from stable to chaotic. A geomorphic explanation for a meander cutoff following channel relocation of a course bedded river was given by Thompson (2003). Joshi and Kale (2005) investigated the anomalous sinuosity in an ephemeral stream in Deccan Trap Region, India. Silva (2006) presented an article on why and how do rivers meander Bend theory of river meanders was proposed by Luchi et al (2011). Güneralp and Marston (2012) investigated the processes and dynamics of linkages. Asahi et al. (2013) conducted numerical simulation of river meandering with self-evolving banks. How the plane shape of the river bank caused meandering of a channel was presented by 
Nagata et al (2014). Matsubara et al (2015) conducted a comparative study of river meandering on Earth and Mars. Słowik (2016) studied the influence of meander bend evolution on the formation of multiple cutoffs. Bogoni et al (2017) modelled morphodynamics of meanders over selfformed heterogeneous floodplains. Yong et al (2018) conducted experimental study on river meander planform pattern. High curvatures driven river meandering was investigated by Sylvester et al (2019). Fluvial and tidal nature of meandering channels were investigated by Finotello et al (2020) using remotes sensing platform. Ielpi and Lapôtre (2020) demonstrated how plants slowed meander migration by ten times.

\section{Study area}

The area selected for the present investigation is located at about $150 \mathrm{~km}$ to the north of Pune in Maharashtra. Pravara River is a tributary of the Godavari River, which rises in Western Ghat and empties itself in the Bay of Bengal. The location map of the study area is depicted in Fig 1. The altitude of river at the source is 1468 ASL. From the source for first $20 \mathrm{~km}$ the river flows with sinuous course in an easterly high relief of Western Ghat, then it falls into a rocky chasm of $61 \mathrm{~m}$ and then winds for about $13 \mathrm{~km}$ through a deep narrow glen with open wider valley. The gradient of Pravara River is 4.2 / 1000 which is sufficiently steep for the movement of gravels. Pravara Valley in the rest of its course

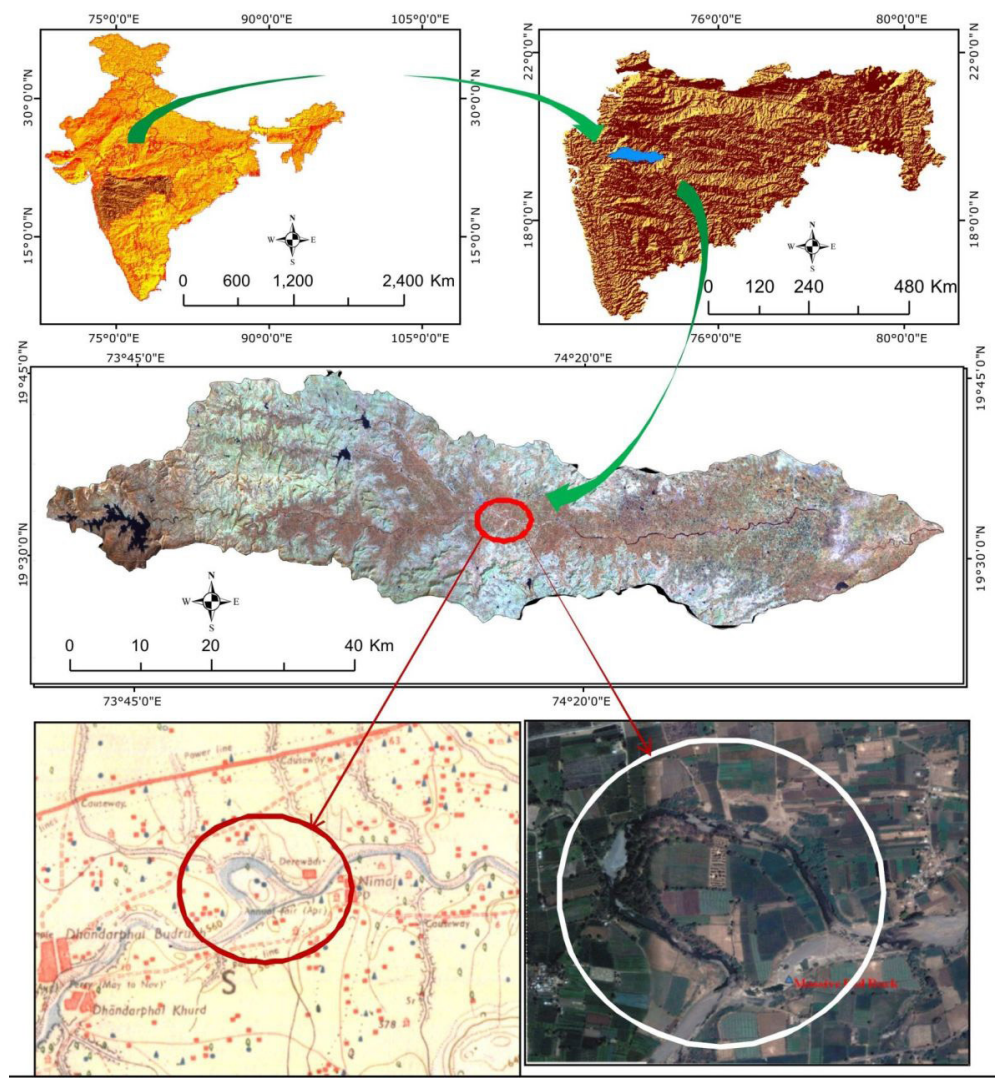

Fig. 1. Location map of the study area, depicting the anomalous cut-off under review 
flows in large, gently undulating, erosional surface and the tributary streams transport very little coarse material.

The entire study area is covered by thick basaltic lava flows of the Deccan Traps belonging to late Cretaceous to Eocene period. According to Kailasm et al (1972), the thickness varies between 500 to 600 $\mathrm{m}$ and is presumed to have been issued on pre-existing rocks ranging from the PreCambrian to Cretaceous age. Several dykes are observed in the vicinity by Geological Survey of India. The widths of these dykes vary from $0.5 \mathrm{~m}$ to $33 \mathrm{~m}$. and some of them have been traced for more than $30 \mathrm{~km}$. Two tectonic features are prominently visible in this region that is Koyna rift and Kurudwadi rift. The regional drainage of the area has been largely controlled by this rift (Kale and Rajaguru, 1986).
Fluvial systems of Upland Western India are affected by the monsoon climate. Since the study area is in the interior region of Maharashtra, the place experiences extreme climatic condition. The area is characterized by hot summer and general dryness during major part of the year except during south west monsoon season. The average rainfall of the basin is $501.8 \mathrm{~mm}$. The site under investigation is covered by thick alluvial fill and black cotton (regur) soil. Vegetation is scanty since it is situated the in the rain shadow zone. Tropical thorny type of vegetation can be observed including acacia and scrubby bushes.

Rivers in Deccan Trap Region do not meander by rule. They flow in deeply incised bedrocks. Floodplains are non-existent anywhere and deep meander loops and cutoffs are virtually absent. However, along

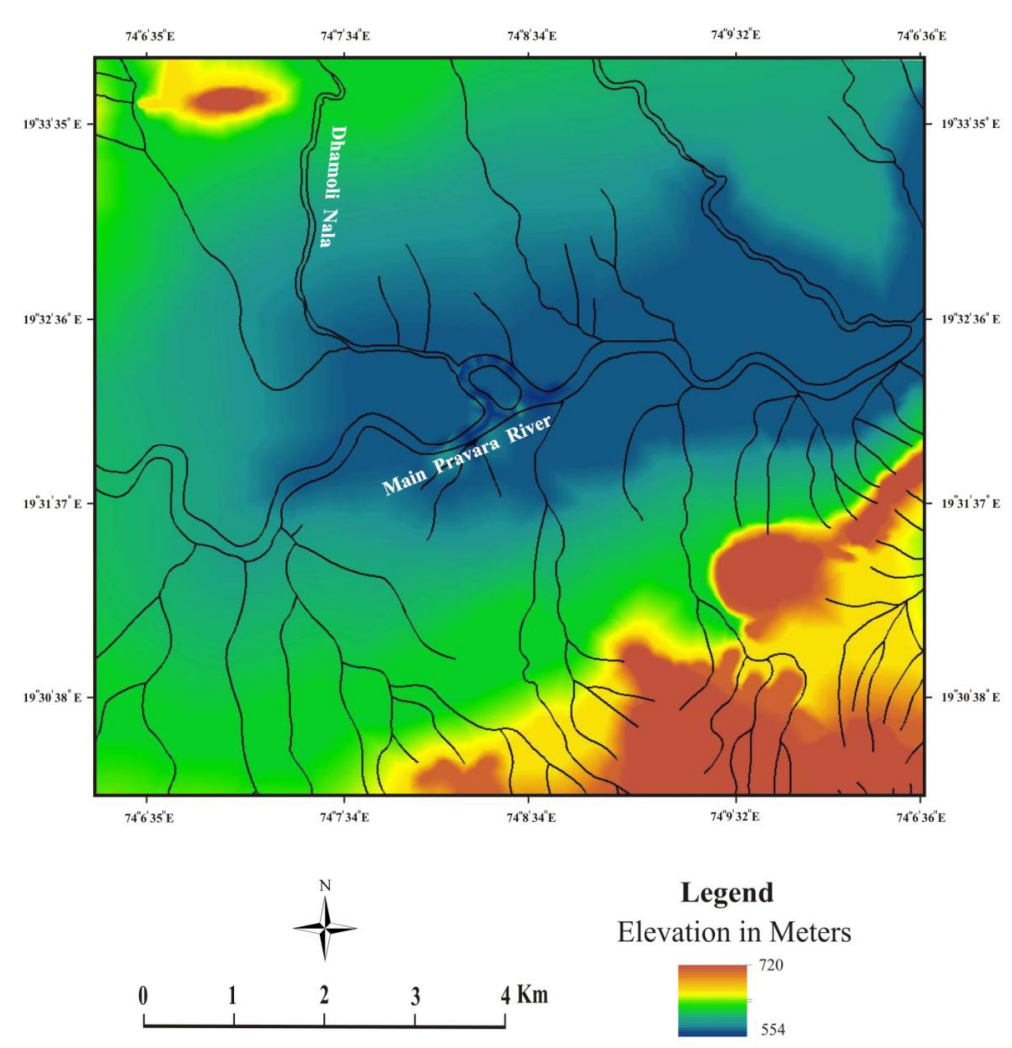

Fig. 2. Digital Elevation Model of the study area 
the course of Pravara River, an anomalous feature is observed which looks like a single cut-off along a straight channel (Fig 1and Fig 2). Some gentle meander bends are present along this channel but the likes of the one mentioned above are not observed anywhere along the entire channel. This loop abruptly pops out of nowhere along a near straight course. There is a link channel the average, width of which is $95 \mathrm{~m}$ and average depth is $4 \mathrm{~m}$. The bend/loop is $51 \mathrm{~m}$ width and depth is $6 \mathrm{~m}$. The entire straight-line length of the loop is $1075 \mathrm{~m}$. The total area occupied by this bend is $0.42 \mathrm{~km}^{2}$. A cursory glance on the feature as seen on the satellite image, Google Earth and topographical map gives an impression of a meander cut-off. However, signatures in the field do not support this observation. A tributary joins right in the middle of this loop, which normally does not happen in meander cut-offs. Hence, an attempt has been made in the present study to understand the mode of formation of this anomalous feature through morphological and sedimentological investigations.

\section{Material and Methods}

The reach of the river where the feature is formed has been clearly demarcated on Survey of India topographical map of 1:50,000 scale. The area under investigation is not very large. Hence DEM was created for the area by digitizing the topographical map, since this will give a higher resolution (20 m) DEM than ASTER or SRTM DEM. The general morphology of the channel reach was determined from the Digital Elevation Model. The morphology of the loop and link-channels were studied by conducting a detailed field survey that includes the measurement of the cross-sections and longitudinal profile of the channel, with the help of Total Station. Lithostratigraphy were mapped at two locations using Miall's (1996) litho-coding system. Sediments were collected from the lithofacies of the two litho-sections and were analysed in the laboratory. Coarser materials were examined in the field itself. The stream power was estimated employing the preexisting formula. Finally, all these results were synthesized to understand the mode of formation of the cutoff bend in the channel.

\section{General Description of the To- pography}

The channel reach under investigation has an irregular topography. The average elevation of this area is $580 \mathrm{~m}$, ASL. Most of the area (about 83\%) is below $600 \mathrm{~m}$ ASL. Only $3 \%$ of area has an elevation of above $700 \mathrm{~m}$ and is located at an isolated part in the southeastern corner of the area. The right bank of Pravara River shows variation in elevation as compared to the left bank. The area more or less represents low relative relief. Most of the area (about 60\%) has relative relief bellow $25 \mathrm{~m}$. The average slope of area is $15 \%$ and about $75 \%$ area has a slope below $10 \%$. Only $2 \%$ of the area has a slope greater than $80 \%$. The right bank of river has the higher slope than left bank. The general trend of slope is very well distributed in all classes with no sign of any bias towards any particular class. Flat areas are mainly found near the channel. The valleys on both sides slope towards the channel.

Fig. 2 demonstrates DEM of the area under review where drainage network can be seen clearly. It is evident from the diagram that a large number of small streams are meeting the channel from both banks. Two major tributaries join the channel from left bank. Out of these two, the one which joins the loop (Dhamoli Nala), plays very important role in our study site. The tributaries from right bank are very small and not very significant.

\section{Geomorphic Map}

A geomorphic map of the study area has been prepared from topographical maps, Google Earth and mostly through field study and is presented in the Fig. 3. Diagram clearly reveals two thalwegs associated with this channel, one passing through the loop and 


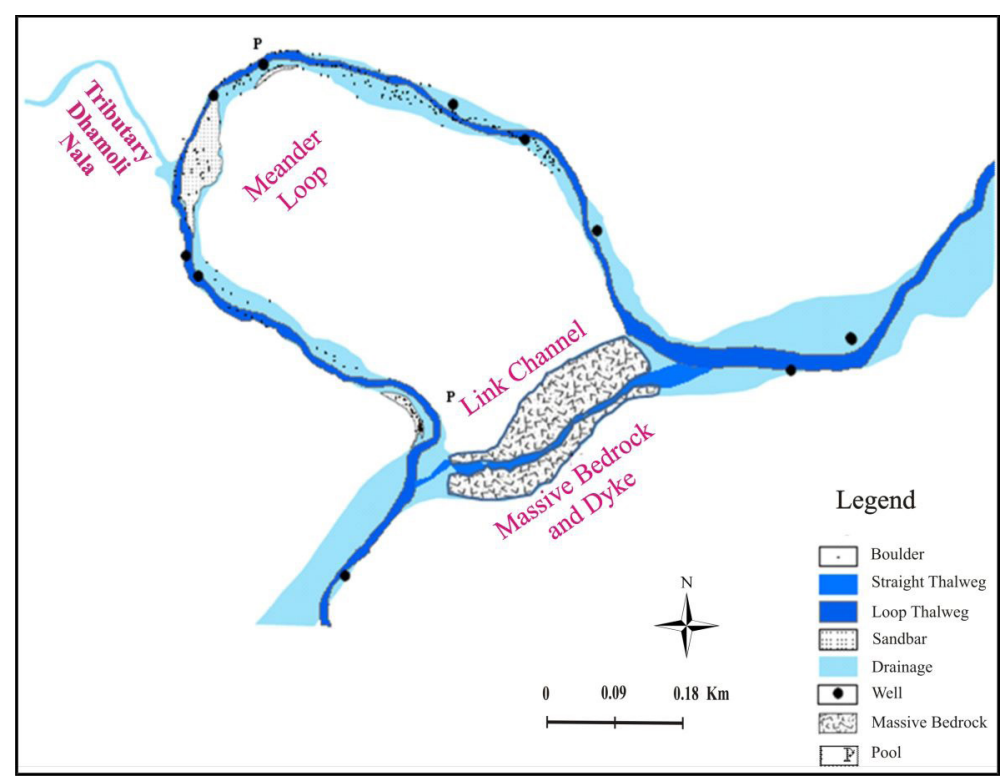

Fig. 3. Geomorphic map of the study area

other through the link channel. Thalweg of the loop is deeper than the one in the link channel. Two prominent crescent shaped point-bars with deep pools are located within the loop. The first one is situated at the starting of the loop and other at the center of the loop. Both are covered with boulders. One midstream bar is also located in between these two point-bars, but is deeply disturbed due to human interferences. Most of the loop bed is covered with the boulders while the bed of the link channel is composed of massive rock covered by coarse sand. One tributary named Dhamoli Nala meets the loop at the central part.

\section{Thalweg Profiles}

The length and slope (gradient) of a channel bed is best illustrated by the thalweg (longitudinal) profile of a channel or in other words, it is a graph of bed-elevation against distance along the channel. Thalweg profile gives us the distribution of the bed of channel, how it changes with distance (from place to place). In the present study two thalweg profiles were surveyed, one along the loop and other in the link channel, in order to understand the bed characteristics of these two paths of channel. The starting point of both the profiles is $400 \mathrm{~m}$ upstream from where the loop is formed and continues $275 \mathrm{~m}$ downstream after the loop ends. Comparing these two profiles can highlight the flow characteristics in the loop and the link channel

\section{Thalweg Profile of Loop}

Fig.4 shows thalweg profiles of the loop, link channel and the superimposed profiles of the two. The profile of the loop is $2160 \mathrm{~m}$ in length that includes $400 \mathrm{~m}$ upstream and 275 $m$ downstream of the actual bend. The actual length of the loop is $1475 \mathrm{~m}$. The profile is rough, indicating the irregularities in bed erosion due to the bedrock characteristics and sediment deposition along the thalweg. The bed elevation ranges from $553.6 \mathrm{~m}$ to $556 \mathrm{~m}$. In the middle part, the bed elevation is higher as there were deposition of sand and gravels. The deeper parts in the sections along the profile indicate the pools.

\section{Thalweg Profile of Link channel}

Length of this profile is $1050 \mathrm{~m}$ (Fig 4). After $400 \mathrm{~m}$ distance from the starting point there is sudden considerable increase in bed 
elevation from 554.8 to $556.8 \mathrm{~m}$ (that is the difference of $2 \mathrm{~m}$ ) and it remains almost the same up to the distance of $775 \mathrm{~m}$. This $375 \mathrm{~m}$ part is massive bedrock covered by sand and gravels. After the distance of $775 \mathrm{~m}$ the slope decreases where the loop ends and regains its original path with a straight course.

\section{Superimposed Thalweg Profiles}

When these two profiles were superimposed, it is vividly clear that (Fig. 4) that there is difference of $2 \mathrm{~m}$ in the bed elevation of these two profiles. That elevated portion is massive resistant bedrock, which could have promoted the diversion of channel from straight to the present curved path.

\section{Cross-Sectional Characteristics}

The shape of the channel determines the area of friction between the flowing water and the channel bed and banks are represented by wetted perimeter. Shallow channels are less efficient because the loss of stream energy increases with increase in the frictional area (as wetted perimeter is larger). In case of narrow channels less frictional area as wetted perimeter is smaller and channel is more efficient. In the present investigation 19 cross-sections were measured, the location of them are depicted in Fig 4 and the graphical presentations of these crosssections are demonstrated in Fig 5 and Fig 6.
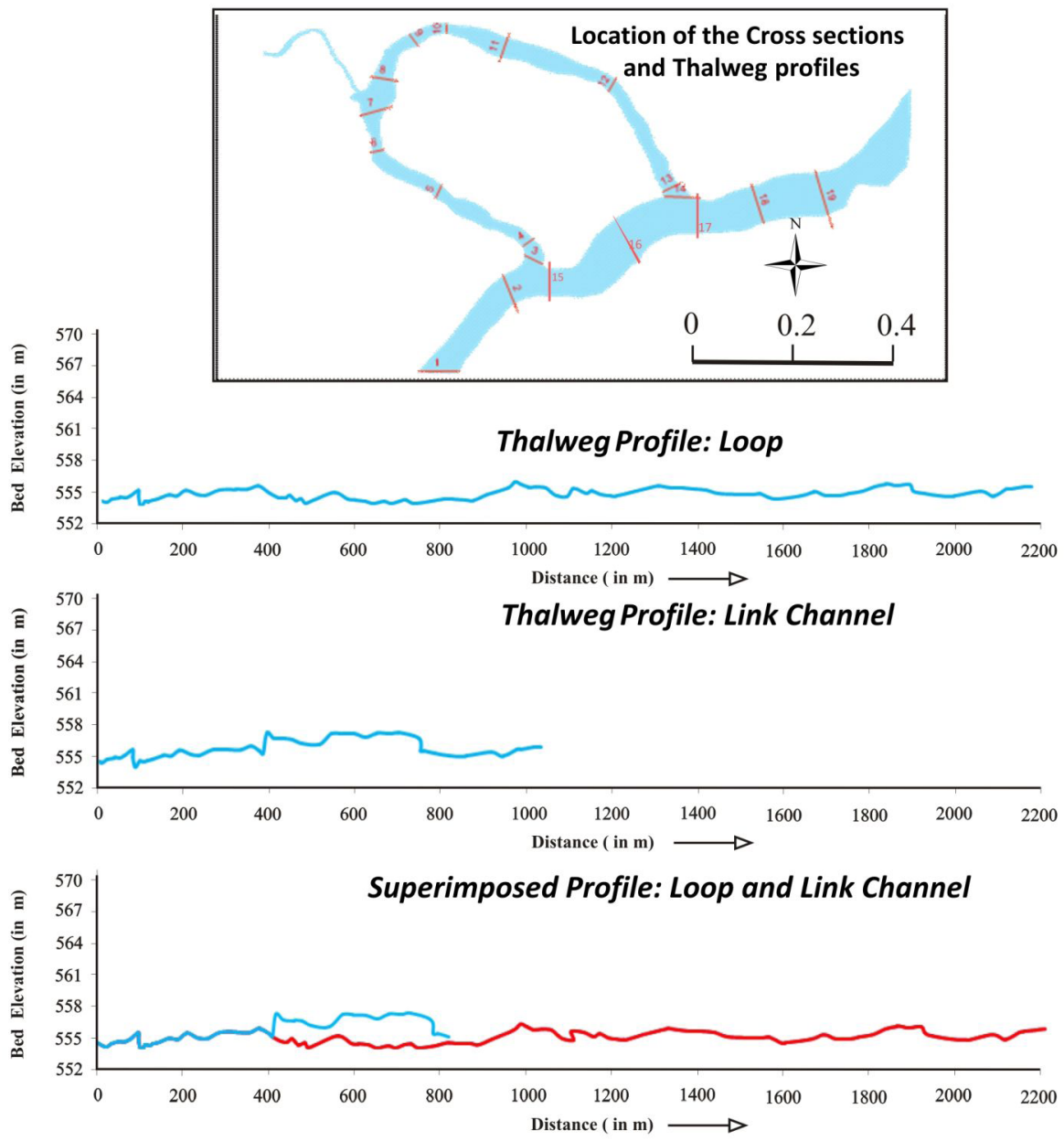

Fig. 4. Diagram demonstrates the location of the cross-sections and also the thalweg profiles of the meander loop, the link channel and the superimposed thaweg profiles 
Fig 7 displays the field views of the river at different sections. The descriptions of these cross-sections are displayed in Table 1.

Table 1. Cross Sectional Characteristics of the channel

\begin{tabular}{cc}
\hline $\begin{array}{c}\text { Sec } \\
\text { No }\end{array}$ & Distance from the starting point \\
& 400 m before the junction (that \\
1 & is the starting point of the loop) \\
Fig. $5(1)$
\end{tabular}

This cross-section is first cross-

3 section of the loop located at the starting of loop, $433 \mathrm{~m}$ away from first cross-section Fig. 5 (3)

This is second cross-section of the loop having steeper right bank with higher elevation. It is located $662 \mathrm{~m}$ from first crosssection Fig. 5 (4)

This is third cross-section of the loop $800 \mathrm{~m}$ away from the starting point and $367 \mathrm{~m}$ from the junction Fig. 5 (5)

It is located $900 \mathrm{~m}$ from the first 6
Width and depth of the channel

Width is $85 \mathrm{~m}$ and max depth is $4 \mathrm{~m}$.

Width is $115 \mathrm{~m}$ and max depth is $3.5 \mathrm{~m}$.

Its width is $71 \mathrm{~m}$ and max depth is $6.6 \mathrm{~m}$

Width of this crosssection is $35 \mathrm{~m}$ and maximum depth is $5 \mathrm{~m}$.

Its width is $41 \mathrm{~m}$ and max depth is $4.6 \mathrm{~m}$

Its width is $46 \mathrm{~m}$ and max depth is about $5.7 \mathrm{~m}$.
Characteristics of the section

The thalweg was passing from both the bank sides as bed was covered by sand. At the right bank it flows through the bed rock. Its right bank is steeper and left bank is gentle

Here the thalweg is dividing into two ways one to the link channel and other towards loop and flows from the middle part of section. From the right side the water goes to the link channel and from left side to the loop. Both the banks are gentle

It is comparatively narrow crosssection It has deeper and steeper right bank and gentler left bank. Left side is deeper as thalweg passes through it.

Left bank of this section is also steep but have relatively lower elevation. It is narrower than the third crosssection. Deeper right side of this cross-section indicates pool and left side has center of the point-bar.

It is narrowest cross-section. It has both banks at near about the same elevation. Here thalweg is shifted from right to left bank, but not very deep, as the bed of cross- -k ngtion ss-section.section is composed of rock covered by sand and gravels.

Not much change in section, it is symmetrical cross-section. Its bed is also composed of rock and covered by gravels, sand and calcretes. Thalweg is located near the left bank. Both the banks are steeper and at same elevation. 
It is located $980 \mathrm{~m}$ from the first cross-section and $547 \mathrm{~m}$ from starting point of loop Fig. 5 (7)

Sixth cross-section of the loop, located after the confluence of the Dhamoli Nala to the loop, $664 \mathrm{~m}$ from the starting of the loop Fig. 5 (8)

It is located at the centre of the loop $700 \mathrm{~m}$ from the starting of loop and $1122 \mathrm{~m}$ from the $1^{\text {st }}$ cross-section Fig. 5 (9)

This section is located $57 \mathrm{~m}$ from $9^{\text {th }}$ cross-section

Fig. 6 (1)

It is $145 \mathrm{~m}$ downstream from the $10^{\text {th }}$ cross-section

Fig. 6 (2)

It is located $1527 \mathrm{~m}$ away from

$1^{\text {st }}$ cross-section and $218 \mathrm{~m}$ away from $11^{\text {th }}$ cross-section Fig. 6 (3)

This is located $1819 \mathrm{~m}$ away from $1^{\text {st }}$ cross-section Fig. 6 (4)
Width is $90 \mathrm{~m}$ and max depth is $6.6 \mathrm{~m}$

Width is $60 \mathrm{~m}$ and max depth is $5.6 \mathrm{~m}$.

Max depth is 5.1 $m$ and the width is $44 \mathrm{~m}$.

This cross-section is narrow and the deepest cross-section of the loop with $7.3 \mathrm{~m}$ depth and 36 $\mathrm{m}$ width,

This is $62 \mathrm{~m}$ wide and $4.3 \mathrm{~m}$ deep

Its width is $34.5 \mathrm{~m}$ and depth is $5 \mathrm{~m}$.

It is shallow crosssection, $52.5 \mathrm{~m}$ wide and $2.5 \mathrm{~m}$ deep.
It is comparatively wider and shallow Fig. 3.11(b.11()). Here the shape changes from symmetrical to asymmetrical. It has thalweg near its right bank that is its inner bank. Its right bank is steeper and left bank is gentler. The bed of this wider crosssection is covered by boulders.

This is narrower than the $7^{\text {th }}$ crosssection with steeper banks. Thalweg passes near the right bank. Its bed is covered by gravels. This is crosssection of the site having disturbed mid-stream bar.

Here, thalweg is shifted towards left and deep part indicates starting of pool. Its left bank is at higher elevation than right bank, distinct layers of depositions. Both the banks are vertical.

Thalweg passes near the left bank as it has pool and right bank has point-bar. Both the banks are high and steep.

It is wider and shallower as compared to the previous cross-sections. It has symmetric bed without irregularities. It has boulders at left bank and coarser sand at right bank. Thalweg passes from the middle part

This is the narrowest cross-section in the loop. Here Thalweg gets divided into two parts, one flows near right bank and other near the left bank. Its banks are steeper with nearly the same elevation. Bed is covered with big boulders. Its left bank shows layers of distinctive sediment facies.

Here the thalweg passes from right side. Its bed is composed of rock which is exposed. Not much sediment load is present here. This cross-section is tilted towards right side with comparatively gentle banks (Fig. 3.11(c)). 
This is the last cross-section of the loop area, located $1819 \mathrm{~m}$ away from $1^{\text {st }}$ cross-section and $1386 \mathrm{~m}$ away from first crosssection of loop Fig. 6 (5)

This is first cross-section of the link channel and third crosssection of the straight reach. It is located $407 \mathrm{~m}$ away from first cross-section and $90 \mathrm{~m}$ away from second cross-section. Fig $6(6)$

This is located $108 \mathrm{~m}$ away from $15^{\text {th }}$ cross-section Fig 6 (7)

It is situated $97 \mathrm{~m}$ away from

17 the $16^{\text {th }}$ cross-section and $760 \mathrm{~m}$ from $1^{\text {st }}$ cross-section Fig 6 (8)

This cross-section is situated after the junction of the loop to the link channel. This is 1885 $\mathrm{m}$ away from $1^{\text {st }}$ cross-section when we follow loop path and

$775 \mathrm{~m}$ when we follow the straight path Fig 6 (9)

This is the last cross-section of both the reaches located 2157

$19 \mathrm{~m}$ from $1^{\text {st }}$ cross-section by looppath and $1047 \mathrm{~m}$ by straight path Fig 6 (10)
It is wide and shallow section having $80 \mathrm{~m}$ width and $3 \mathrm{~m}$ max depth.

Its width is $37 \mathrm{~m}$ and depth is $3 \mathrm{~m}$.

It is $115 \mathrm{~m}$ wide and the max depth is $9.7 \mathrm{~m}$.

This is wide and shallow section with $112 \mathrm{~m}$ width and $2.4 \mathrm{~m}$ depth.

Its width is $81 \mathrm{~m}$ and depth $3 \mathrm{~m}$.

Width of this section is $120 \mathrm{~m}$ and depth is $3 \mathrm{~m}$.
Bed of this section is composed of massive bedrock with prominent dyke (Fig. 7).

Bed is composed of massive rock, difficult to erode. When we compare the bed elevation of second crosssection and loop cross-section, with this cross-section, the bed elevation of this cross-section is higher than those cross-sections. Here, thalweg passes from right bank. Right bank is gentle and left bank is steeper with high elevation.

Thalweg passes from middle part over the massive bedrock covered by gravels and sand. Here the left bank side shows deeper part it is due to the shifting of bank by the process of erosion. Both the banks are highly elevated and steeper. Banks are composed of compact silty material.

Bed is covered by gravels and sand. Here there is sudden fall in bank elevation, both the banks show lower elevation than previous one.

Here we can see sudden decrease in bed elevation. Thalweg passes from left bank-side and deposition of sand near the right bank which is disturbed due to human interference. Right bank is gentler and less elevated than left bank.

It is shallow and the widest crosssection with asymmetric shape. Here thalweg passes from left side and deposition at opposite side with gentle right bank. 

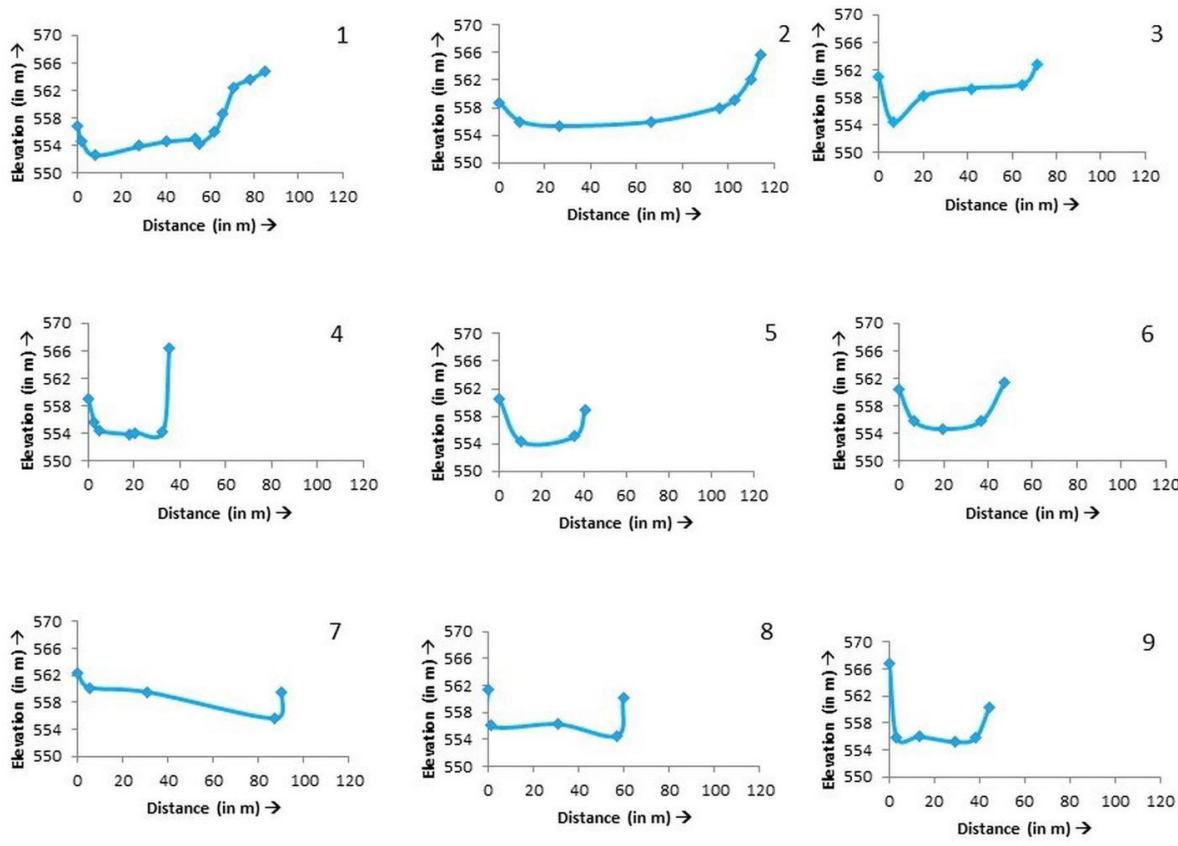

Fig. 5. Cross-sections taken along the loop of the meander
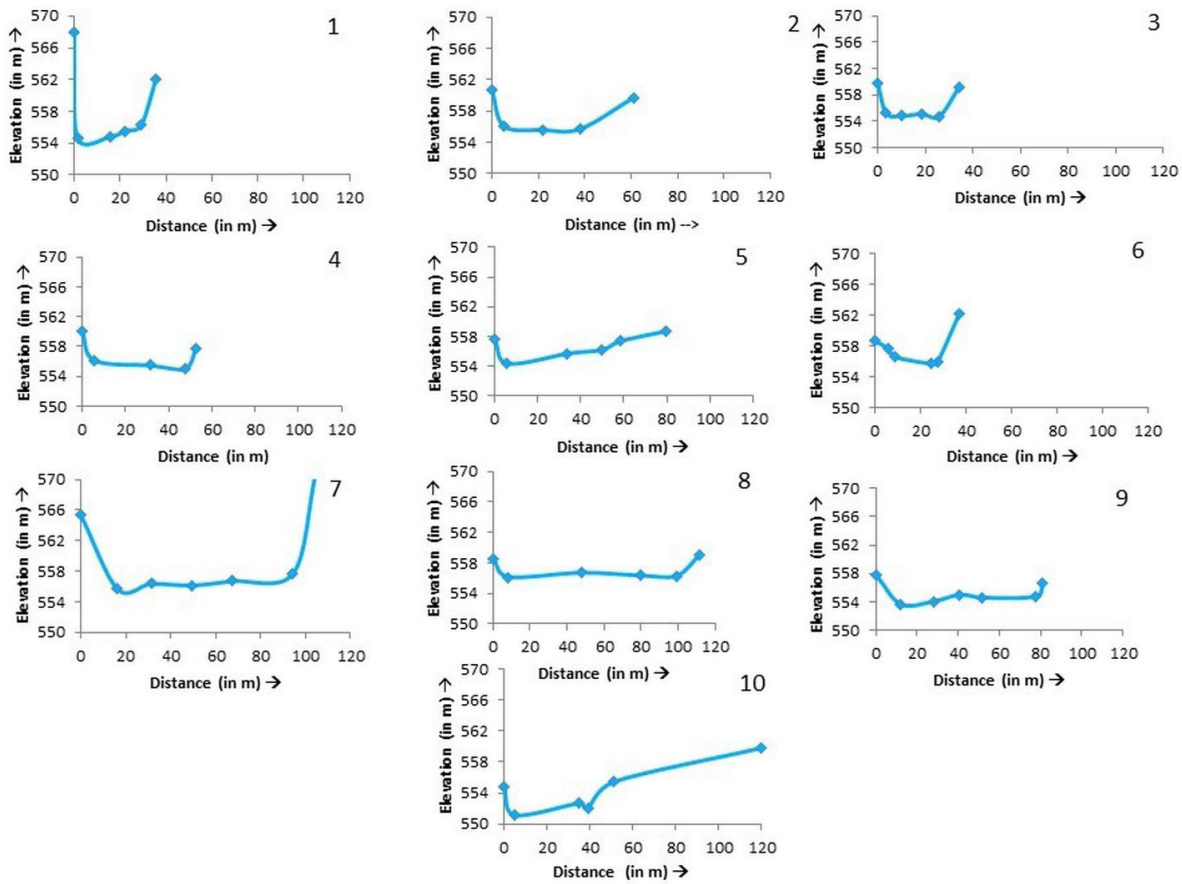

Fig. 6. Cross-sections taken along the loop of the meander and the link channel 


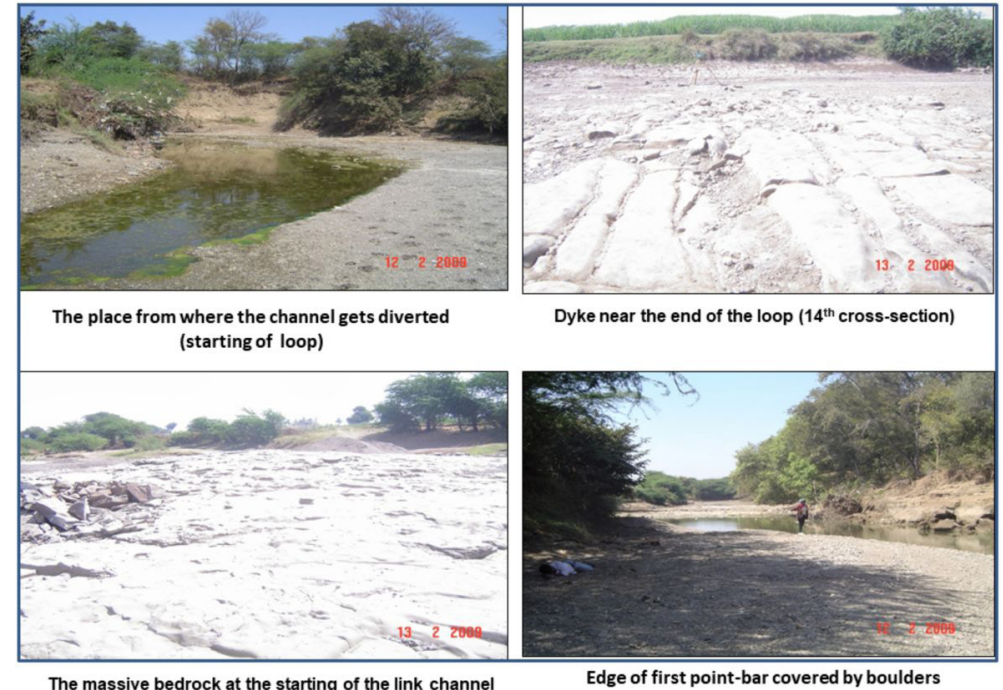

Fig. 7. Field views of the channel at four parts of the channel under investigation

\section{Sedimentological Characteristics}

Sedimentological characteristics are an important parameter in fluvial geomorphology as it helps to reveal the hydrogeomorphic conditions directly or indirectly prevailing during the time of deposition. In the present study, the lithostratigraphy, grain size and shape have been investigated to understand the mode of deposition of these sediments, which will highlight the dynamism of the channel processes. For large size particles, measurements were done in the field itself by taking 2 by 2 squares quadrant at six different locations and finer sediments were collected from the lithosections and were analyzed by sieving and sedigraph techniques. The link channel is massive bedrock littered by coarse gravels and sand. Hence the study of sediment has been concentrated only for the meander loop, not for the link channel.

\section{Size Characteristics}

Grain size analysis is an integral part of the geomorphic studies and it has been employed in the present study mainly to understand the type of sediment population that forms the deposits. Samples were collected from the exposed litho-sections and the channel bed and their textural characteristics were studied by sieve analysis and sedigraph techniques. The particle size statistics of these samples were calculated by employing Folk and Ward (1957) method. The results of the granulometric analysis are presented in Table 2 and Fig $8 \mathrm{a}$ and $\mathrm{b}$. The textural characteristics and grain size statistics demonstrate considerable variation in the energy level when these sediments were deposited. Fining upward sequence up to the middle of the litho-section and then coarsening upward could be observed in both the sections. This is typical of fluvial deposits with varying flow characteristics. It indicates intermittent flood and low discharge regimes during their deposition.

\section{Shape Characteristics}

Shape of the particles reveals several ideas on how long has a grain been transported and it also suggests the source area of the grain and their depositing agents. In the present study, thirteen samples from five different sites were collected from the channel bed and analyzed. Table 3 shows shape characteristics of all the thirteen samples. Among the 13 samples, 
Table 2. Sediment Size Characteristics

\begin{tabular}{|c|c|c|c|c|c|c|c|c|c|c|}
\hline $\begin{array}{c}\text { Sample } \\
\text { No. }\end{array}$ & Description & Mean & $\begin{array}{l}\text { Mode } \\
(\mathrm{mm})\end{array}$ & Median & $\begin{array}{l}\text { Sorting } \\
\text { index }\end{array}$ & $\begin{array}{c}\text { Skewness } \\
0.68\end{array}$ & Kurtosis & $\begin{array}{l}\text { Sand } \\
\%\end{array}$ & $\begin{array}{l}\text { Silt } \\
\%\end{array}$ & $\begin{array}{c}\text { Clay } \\
\%\end{array}$ \\
\hline $\begin{array}{l}\text { Section:1 } \\
\text { Facie:1 }\end{array}$ & $\begin{array}{l}\text { Upper layer } \\
\text { Silty clay }\end{array}$ & 0.093 & 0.250 & 0.08 & $\begin{array}{c}1.96 \\
\text { Poorly } \\
\text { sorted }\end{array}$ & $\begin{array}{c}.0051 \text { Near } \\
\text { symmetrical }\end{array}$ & .92 Mesokurtic & 58 & 40 & 2 \\
\hline $\begin{array}{l}\text { Section:1 } \\
\text { Facie:2 }\end{array}$ & Coarse sand & 0.26 & 0.25 & 0.31 & $\begin{array}{c}1.72 \\
\text { Poorly } \\
\text { sorted }\end{array}$ & $\begin{array}{l}\text { 0.19 Finely } \\
\text { skewed }\end{array}$ & 0.92 Mesokurtic & 86 & 13.25 & .75 \\
\hline $\begin{array}{l}\text { Section:1 } \\
\text { Facie:3 }\end{array}$ & Silty clay & 0.16 & 0.25 & 0.15 & $\begin{array}{c}1.75 \\
\text { Poorly } \\
\text { sorted }\end{array}$ & $\begin{array}{l}0.028 \text { Near } \\
\text { symmetrical }\end{array}$ & 0.82 Platykurtic & 74 & 24.50 & 1.5 \\
\hline $\begin{array}{l}\text { Section:1 } \\
\text { Facie: } 4\end{array}$ & Clayey facie & 0.25 & 1 & 0.5 & $\begin{array}{l}2.33 \\
\text { Very } \\
\text { Poorly } \\
\text { sorted }\end{array}$ & $\begin{array}{c}0.52 \\
\text { Strongly } \\
\text { Fine skewed }\end{array}$ & 0.68 Platykurtic & 75 & 24.20 & 0.8 \\
\hline $\begin{array}{l}\text { Section:1 } \\
\text { Facie:5 }\end{array}$ & $\begin{array}{l}\text { Lithifide } \\
\text { gravel }\end{array}$ & 3.41 & 4 & 3.03 & $\begin{array}{c}1.67 \\
\text { Poorly } \\
\text { sorted }\end{array}$ & $\begin{array}{c}-0.15 \text { Coarse } \\
\text { Skewed }\end{array}$ & 1.09 Mesokurtic & & & \\
\hline $\begin{array}{l}\text { Section:2 } \\
\text { Facie:1 }\end{array}$ & $\begin{array}{l}\text { Upper layer } \\
\text { Top soil }\end{array}$ & 0.084 & 0.100 & 0.083 & $\begin{array}{c}1.06 \\
\text { Poorly } \\
\text { sorted }\end{array}$ & $\begin{array}{c}0.019 \text { Near } \\
\text { symmetrical }\end{array}$ & 1.1 Mesokurtic 0 & 64 & 34.9 & 1.1 \\
\hline $\begin{array}{l}\text { Section:2 } \\
\text { Facie:2 }\end{array}$ & Silty clay & 0.09 & 0.250 & 0.072 & $\begin{array}{c}2.02 \\
\text { Very } \\
\text { Poorly } \\
\text { sorted }\end{array}$ & $\begin{array}{l}-0.09 \text { Near } \\
\text { symmetrical }\end{array}$ & 1.01 Mesokurtic & 55 & 41 & 4 \\
\hline $\begin{array}{l}\text { Section:2 } \\
\text { Facie: } 3\end{array}$ & Clayey facie & 0.114 & 0.250 & 0.092 & $\begin{array}{c}1.98 \\
\text { Poorly } \\
\text { sorted }\end{array}$ & $\begin{array}{l}\text {-0.125 Near } \\
\text { symmetrical }\end{array}$ & 0.94 Mesokurtic & 64 & 33.9 & 2.1 \\
\hline $\begin{array}{l}\text { Section:2 } \\
\text { Facie: } 4\end{array}$ & Coarse sand & 0.60 & 1 & 0.76 & $\begin{array}{c}2.16 \\
\text { Very } \\
\text { Poorly } \\
\text { sorted }\end{array}$ & $\begin{array}{l}0.21 \text { Finely } \\
\text { skewed }\end{array}$ & 0.99 Mesokurtic & 91 & 8.5 & 0.5 \\
\hline $\begin{array}{l}\text { Section:2 } \\
\text { Facie:5 }\end{array}$ & $\begin{array}{l}\text { Lithified } \\
\text { gravel }\end{array}$ & 3.31 & 4 & 2.64 & $\begin{array}{c}2.57 \\
\text { Very } \\
\text { Poorly } \\
\text { sorted }\end{array}$ & $\begin{array}{c}-0.24 \text { Coarse } \\
\text { Skewed }\end{array}$ & 1.11 Mesokurtic & & & \\
\hline
\end{tabular}




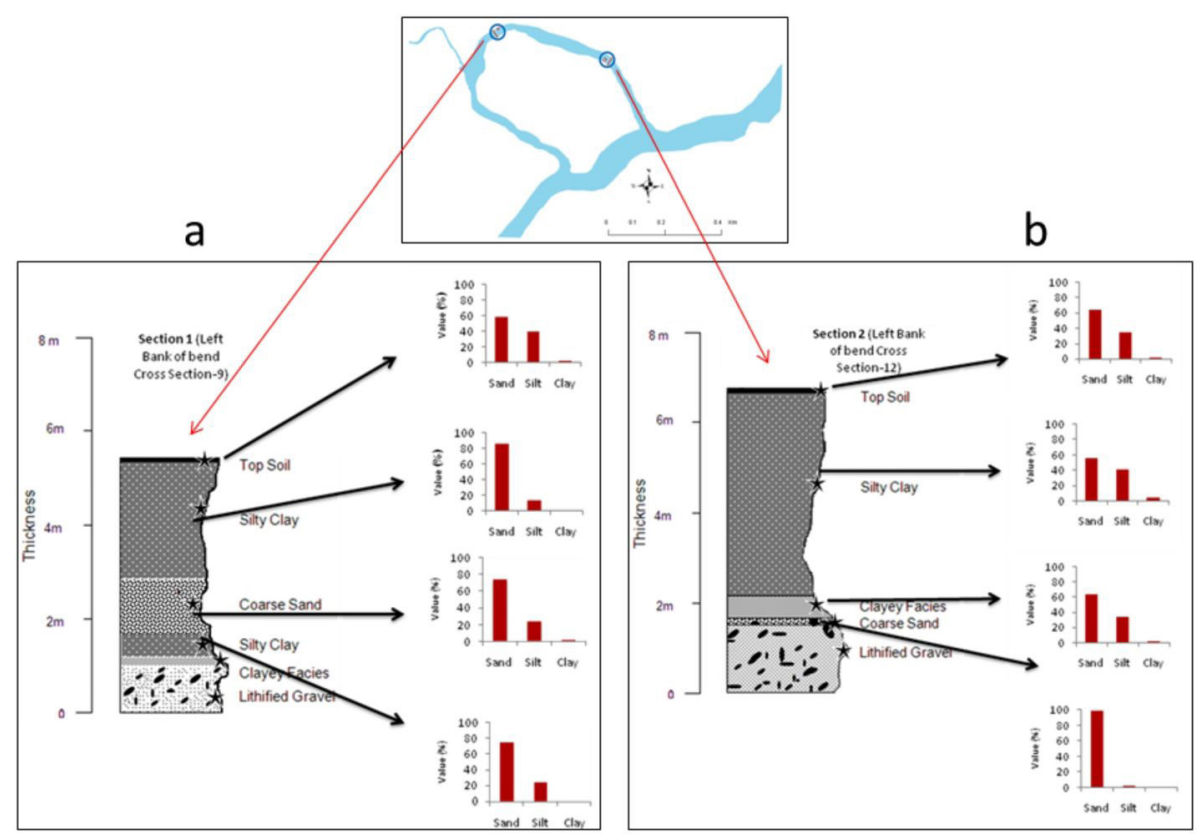

Fig. 8. Two litho-sections and their locations, as well as, the depth wise textural characteristics of the sediments are illustrated in this figure

5 were selected as the representative, each one representing a cluster. They have been plotted in Zingg's (1964) diagram and depicted in Fig. 9. As we can see in the figure, oblate shape is uniformly present in all the sites (it is the most frequently occurring shape this area) and second most frequently occurring shape is bladed shape which is dominant up to half of the loop and then it decreases. For the last site it (bladed) again becomes dominant. Proportion of prolate also goes on increasing with distance. Equant shape is the least frequently occurring shape. Analysis indicates that very little material is transported from longer distance and most of the sediment load is from the local region. It may be from that region only, scoured by the process of erosion when the path of channel gets diverted. Table 4 depicts distance against the largest clasts for six sites. A bivariate relationship was obtained between the distance and largest clast where the trend line depicts positive value but $r$ value is very small $(r=0.16)$. This indicates that there is no relationship between distance and largest size. The size of gravels randomly changes with respect to distance, indicating random deposition. The largest clast was found in the 9th cross section.

\section{Litho-Stratigrapy of the deposits}

Litho-facies analysis is mainly employed in geomorphology and geology to elucidate the entire sequence of depositional environment. In the present study two litho-sections were investigated from outer bank of the meander loop which are very prominent in this area (Fig. 10). First litho-section was taken at 9th cross-section which was $1131.15 \mathrm{~m}$ from the starting point and second was taken at 396.50 $\mathrm{m}$ downstream from the 1 st litho-section. The locations of these two litho-sections can be seen in Fig 8. Facies identification were done by employing Miall's (1996) classification.

\section{Litho-section: 1}

Fig. 8 a, Fig. 10 a and Fig 11 a, depict litho-section no 1 . The height of the section is $5.3 \mathrm{~m}$. The most frequently occurring 

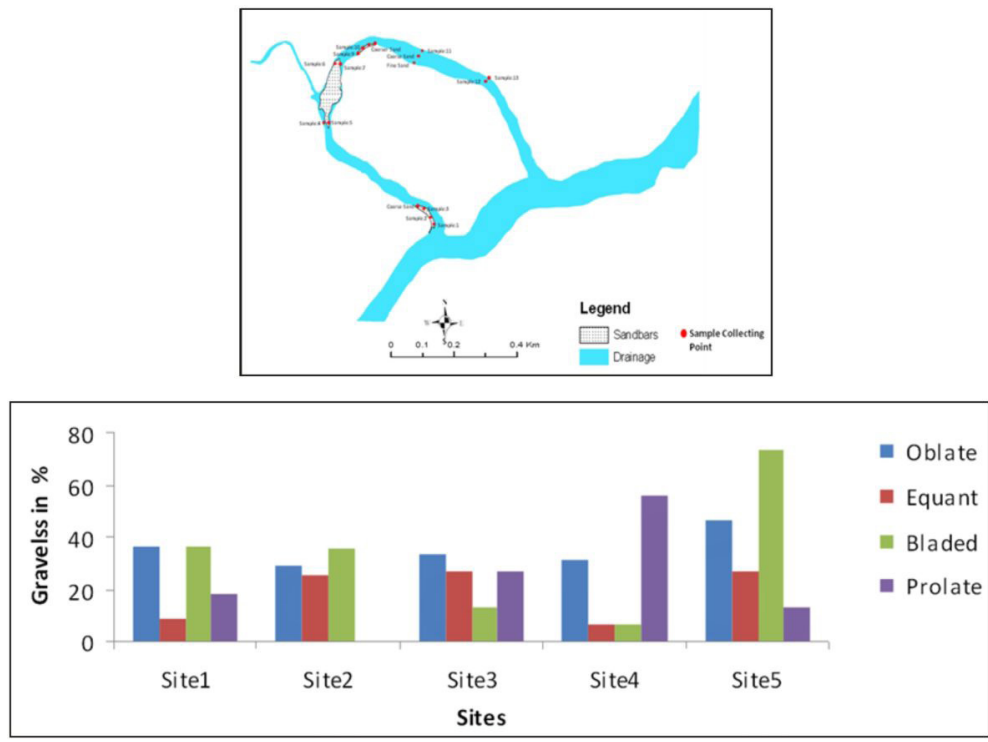

Fig. 9. Sediment shape characteristics (Zingg 1935) at five locations, each one representing a cluster. The locations of the samples are also displayed in the diagram

Table 3. Sediment Shape Characteristics

\begin{tabular}{|c|c|c|c|c|c|}
\hline Site & Location & $\%$ of Oblate & $\%$ of Equant & $\%$ of Bladed & $\%$ of Prolate \\
\hline \multirow{3}{*}{$\begin{array}{l}\text { Cross Section-4 } \\
\text { Point bar-1 } \\
\text { (Outer Bank) }\end{array}$} & $1^{\text {st }}$ edge & 50.00 & 10.00 & 10.00 & 30.00 \\
\hline & $\begin{array}{l}\text { Middle part ( } 20 \mathrm{~m} . \\
\left.\text { from } 1^{\text {st }} \text { edge }\right)\end{array}$ & 36.36 & 9.09 & 36.36 & 18.18 \\
\hline & $40 \mathrm{~m}$. from $1^{\text {st }}$ edge & 25.00 & 25.00 & 33.33 & 16.67 \\
\hline \multirow{2}{*}{ Cross Section-7 } & Outer Bank & 35.71 & 28.57 & 14.29 & 21.43 \\
\hline & Inner Bank & 29.41 & 35.29 & 35.29 & 0.00 \\
\hline \multirow{3}{*}{ Cross Section-8 } & Outer Bank & 20.00 & 46.67 & 13.33 & 20.00 \\
\hline & Middle Channel & 29.41 & 35.29 & 11.46 & 23.53 \\
\hline & Inner bank & 33.33 & 26.67 & 13.33 & 26.67 \\
\hline \multirow{2}{*}{$\begin{array}{l}\text { Cross Section-9 } \\
\text { Point bar-2 } \\
\text { (Inner bank) }\end{array}$} & $1^{\text {st }}$ edge & 40.00 & 13.33 & 06.67 & 40.00 \\
\hline & $30 \mathrm{~m}$. from $1^{\text {st }}$ edge & 31.25 & 06.25 & 06.25 & 56.25 \\
\hline Cross Section-11 & Outer Bank & 46.67 & 26.67 & 13.33 & 13.33 \\
\hline \multirow{2}{*}{ Cross Section-12 } & Outer Bank & 40.00 & 26.67 & 06.67 & 26.67 \\
\hline & Middle Channel & 40.00 & 13.33 & 20.00 & 26.67 \\
\hline
\end{tabular}


Table 4. Largest Clast against Distance

\begin{tabular}{ccc}
\hline Site No & $\begin{array}{c}\text { Distance } \\
(\mathrm{m})\end{array}$ & $\begin{array}{c}\text { Largest Clast } \\
(\mathrm{cm})\end{array}$ \\
\hline 1 & 625 & 14 \\
2 & 970 & 17 \\
3 & 1095 & 15 \\
4 & 1131 & 24 \\
5 & 1527 & 11.5 \\
6 & 1680 & 20 \\
\hline
\end{tabular}

facie in the litho-section is silty-clay which occurs twice in the sequence, that is $2 \mathrm{nd}$ and 4 th facies from top. It is denoted as Fl. The topmost part of the litho-section is covered by very thin layer of black soil. Second most frequently occurring facie is coarse sand which is $1.2 \mathrm{~m}$ thick, denoted by Sh. It is 3rd facies located in between two silty-clay facies. Below that a thin layer of compactly arranged clay is present (thickness $=0.1 \mathrm{~m}$ ). This facie is denoted by Fsm. The bottom layer is a lithified gravel layer embedded with small pebbles in it. It is denoted by Gm. It is very poorly sorted. The mean phi-size ranges from 3.41 to 0.093 (Table 2), which shows highest for the lithified gravel, located at the bottom of the section and it decreases (as size decreases) towards the top. All the facies are poorly sorted (Fig 11 a) suggesting varying energy conditions of depositing medium. Skewness is positive for almost all the facies except the bottom lithified gravel, implying dominant coarser material at the bottom layers but more fine material in the upper sections. Last two layers are platykurtic and above that are mesokurtic in nature with values ranging from 0.7 to 1.1 .

\section{Litho-section: 2}

This litho-section 2 (Fig. 8 b, Fig. 10 b and Fig. $11 \mathrm{~b}$ ) is comparatively thicker than the 1st litho-section. Five distinct facies can be identified in this $7.5 \mathrm{~m}$ thick lithosection. Here, the most frequently occurring
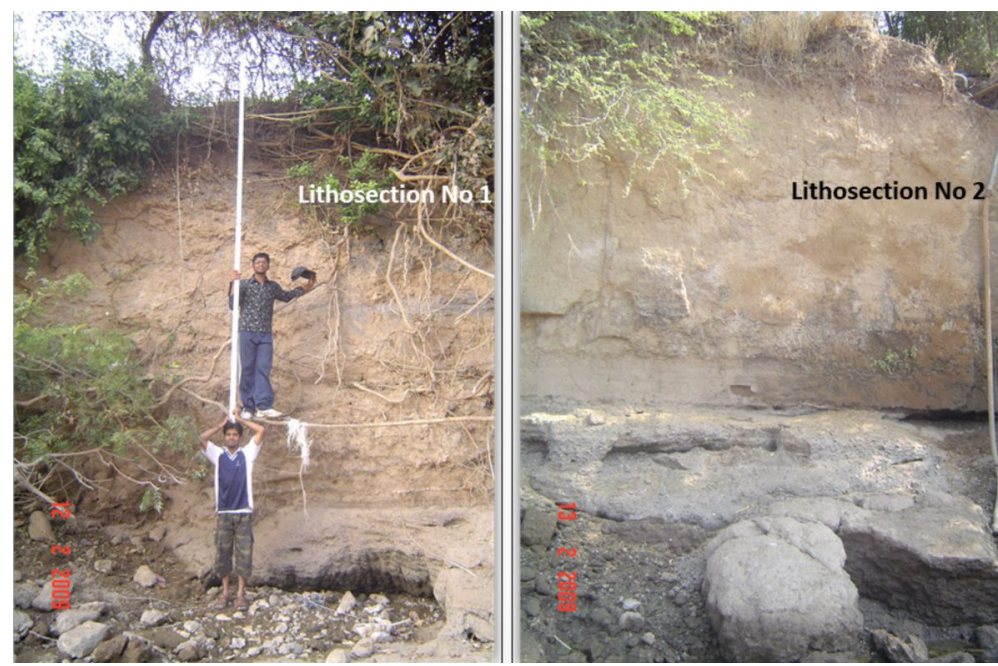

Fig. 10. Field views of the two litho-sections within the meander loop 

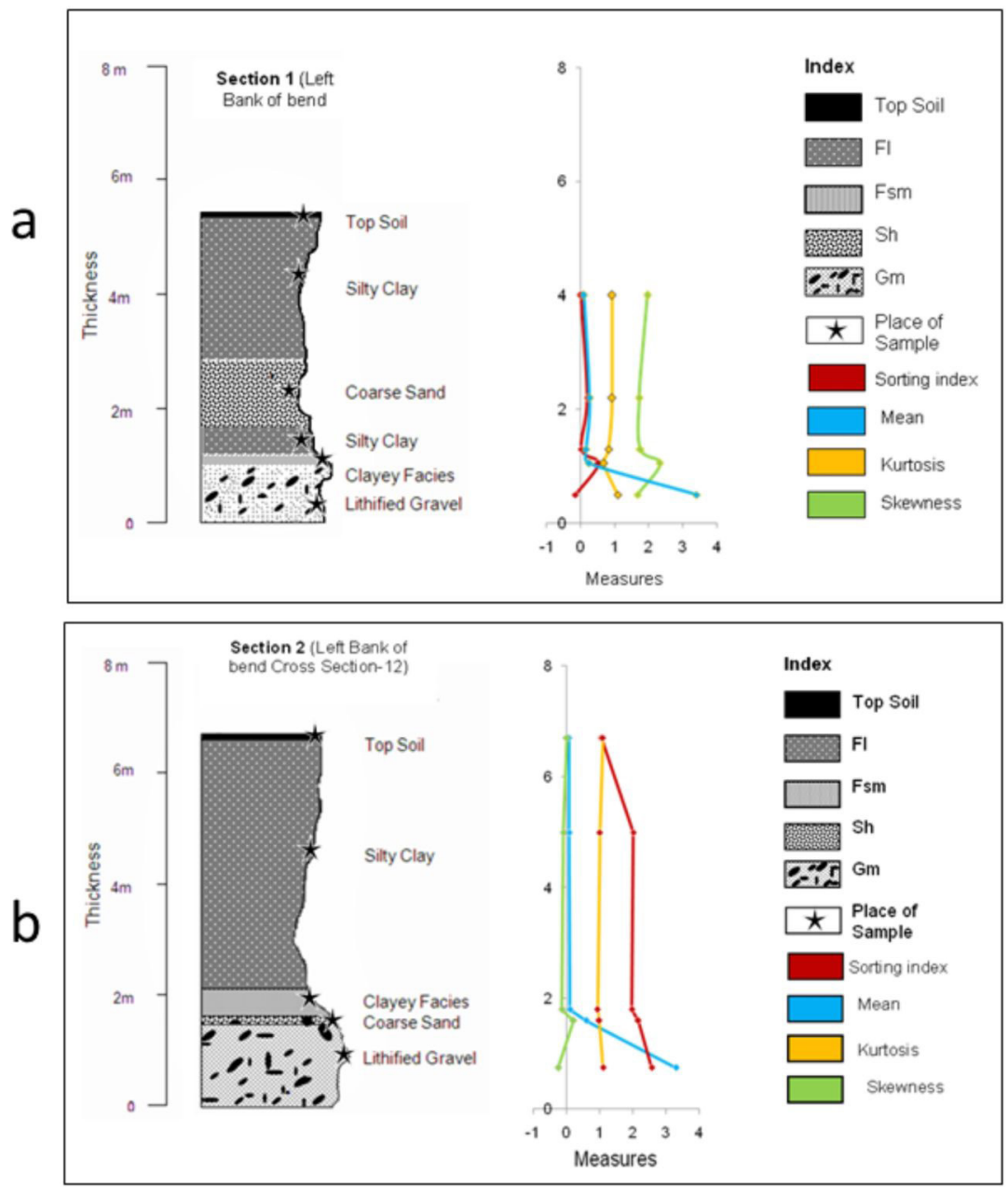

Fig. 11. Two litho-sections with the litho-codes described by Miall (1996). The depth wise variations in the sediment size statistics also are depicted in the diagram

facie is lithified gravel with pebble matrix. The thickest facie is silty-clay denoted by $\mathrm{Fl}$ and thickness is $4.5 \mathrm{~m}$. It is very compactly arranged. The uppermost thin layer is covered by black soil. Below the silty-clay, the 3rd facie is compact clay layer. It is $0.5 \mathrm{~m}$ thick layer of fine silt denoted by Fsm. A very thin layer of coarse sand is observed above the bottom layer. It is very poorly sorted having thickness of $0.15 \mathrm{~m}$ denoted by $\mathrm{Fl}$. Second most occurring facie is the lithified gravel with small pebbles embedded in it. Its thickness is $1.5 \mathrm{~m}$ denoted by $\mathrm{Gm}$. In both the litho-sections, the percentage of sand decreases towards upper facies, whereas silt and clay increase toward upper facies. Silty-clayey facie in section 1 did not follow this sequence. Mean phi-size decreases upward the section, such as, from bottom to the top, with the values ranging from 3.31 to 0.08 (Table 2, Fig 11 b.). All facies are very poorly sorted indicating variability in energy levels of depositing medium. All the facies are mesokurtic i.e. normally distributed. Skewness is positive for top soil and coarse sand, whereas it is negative for other three facies suggesting coarser fractions in these facies (Fig $11 \mathrm{~b}$ ). 


\section{Hydraulic Characteristics of the Loop}

A common practice in fluvial geomorphology is to employ sediment size to calculate unit stream power, shear stress and mean velocity of the stream. An attempt has been made in the present study to calculate the threshold values of the shear stress of the bed and mean velocity required to transport these gravels by using Williams, (1983) equation;

The equations used to estimate the parameters are as follows;

$$
\begin{gathered}
\text { Mean velocity }=0.065 d^{0.5} \\
\text { Shear stress }=0.17 d
\end{gathered}
$$

(Here the diameter $(\mathrm{d})$ is the average value of long axis, intermediate axis and short axis)

It can be inferred from Table 5 that the mean velocity for the entrainment of these deposits range from $0.64 \mathrm{~m} / \mathrm{s}$ to $0.77 \mathrm{~m} / \mathrm{s}$. The value of shear stress ranges between $16.44 \mathrm{Nm}^{-2}$ to $24.09 \mathrm{Nm}^{-2}$. There is considerable increase in the velocity at the 9 th cross section.

\section{Results}

The overall assessment of the crosssectional data reveals that the channel bed of the loop is deeper than the link channel and the present erosion is directed to the loop channel and not in the link channel. It is also evident that the channel was flowing along the near straight course, (the present link channel) until it encountered the bedrock and a major event triggered its path to divert from the original path. Within the loop, channel displays all the meander morphology.

The textural characteristics and grain size statistics demonstrate considerable variation in the energy level when these sediments were deposited. Fining upward sequence up to the middle of the litho-section and then coarsening upward could be observed in both the litho-sections. This is typical of fluvial deposits with varying flow characteristics, such as, intermittent flood and low discharge regimes.

The overall picture that emerges out of shape analysis is that majority of the samples were not long transported and source region is near. Few sediments could be incorporated from the mass movement of the bank material as well.

Litho-stratigraphical analysis shows that the sequence of facies in both sections is nearly the same. Mean phi-size ranges also are nearly the same, which decreases from bottom to top in both the litho-sections. All the facies are poorly sorted indicating variability in energy levels of depositing medium. Upper facies of both litho-sections have excessive finer material and bottom lithified gravel have dominant coarser material (exception in second litho-section where clayey facie shows more of coarser material). All the facies in both litho-sections are mesokurtic i.e. normally distributed. Exceptionally coarse sand and silty-clay fall between low peaked platykurtic.

Table 5. Site wise Mean Velocity and Shear Stress of Mid-Stream Bar

\begin{tabular}{cccc}
\hline Site No. & $\begin{array}{c}\text { Diameter } \\
(\mathrm{mm})\end{array}$ & $\begin{array}{c}\text { Mean Velocity } \\
(\mathrm{m} / \mathrm{s})\end{array}$ & $\begin{array}{c}\text { Shear Stress }(\mathrm{r}) \\
\left(\mathrm{Nm}^{-2}\right)\end{array}$ \\
\hline 1 & 96.7 & 0.64 & 16.44 \\
2 & 123.3 & 0.72 & 20.96 \\
3 & 126.7 & 0.73 & 21.54 \\
4 & 141.7 & 0.77 & 24.09 \\
5 & 78.3 & 0.58 & 13.31 \\
6 & 133.3 & 0.75 & 22.66 \\
\hline
\end{tabular}


The sheer stress of the channel reach under review reveals that the discharge at the time of deposition must have been several magnitudes higher than the present one. The present scenario is that there is discharge only during the monsoon season and very little water is present once the monsoon ceases.

\section{Discussion and Conclusion}

The channel under investigation is a small part of Pravara River, which is a bedrock channel. The channel follows a near straight path and suddenly turned unusually in this reach which is unusual in the area. It gives an appearance of a 'cut-off' from the topographical map and satellite image but in the field, it shows different characteristics. Also, it is not a usual meander as one tributary is meeting at the center of the loop of the meander, which is very unlikely for a meander cut-off. In case of natural cut-off, river shortens its length by cutting off the path and gains renewed competence. Subsequently, loop dries out after abandonment and water can be there only when there is high discharge or flood conditions. In the present case, the river water flows through the loop instead of
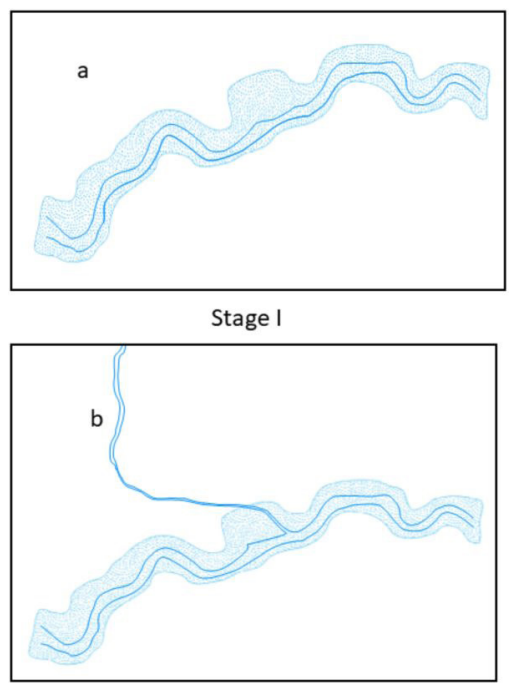

Stage II straight course and the link channel is dry. There is field evidence that sometimes water flows through it at high discharge or flood conditions. This is definitely an anomaly. The link channel bed is composed of massive bedrock and it is at higher elevation than the bed of the channel loop.

Such major changes in the river characteristics occur only due to reasons, such as, tectonic activity, high flood induced channel diversion or morphologic adjustment of the river. No tectonic signature was found anywhere within the vicinity. Even if there were, it would not have been restricted only to this reach to cause this dramatic loop. It would have manifested everywhere in the surrounding. On the basis of the data generated in the study and actual observations in field, the following hypothesis has been presented that possibly explains the formation of this anomalous feature. The possible sequences of the channel shifting are depicted in the Fig 12.

- 1 - River was flowing over the selfgenerated alluvium with a near straight path in this reach (Fig 12 a).

- 2 - River erodes vertically through the soft alluvium. A tributary joins it from the left bank (Fig 12 b).

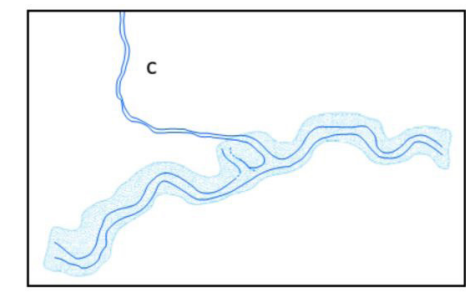

Stage III

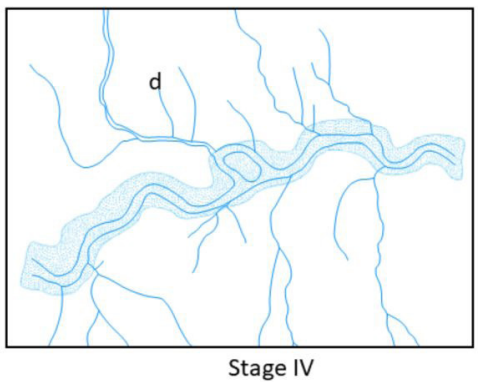

Fig.12. Diagram depicts the possible stages of the development of the meander loop 
- Stage 3 - As the river undercuts, it encounters bedrock and its linear erosion is retarded. During such condition, when the river is incompetent to cut vertically, any triggering mechanism could induce channel diversion, as it was already looking for an easier alternative path. This was when the river started eroding the banks laterally. A big flood must have caused the river to overflow the banks. Once the flood receded, the channel must have found a link to the tributary as shown in the Fig 12 c.

- Stage 4 - Few such instances would have led to the river discarding its old path and took the diversion path, cutting over the softer alluvium as depicted in the Fig 12 d. Litho-stratigraphical sequences and sediment size statistics revealed higher discharge in the past along the channel in this sector.

This is a classic example of natural morphological adjustment of a river when a set of events occurred, first retardation of vertical erosion encountering bedrock, followed by series of floods and finally a tributary guiding the first course of the diversion until it winded to resume the present path. It can be expressed either way as right (wrong) situation at the right (wrong) time for the formation of this single cut-offlike feature at a very unlikely place. The study has been able to highlight certain aspects of the fluvial systems and hydro-geomorphic condition of this reach along Pravara River. This is a clear case of a river which has left a very unlikely signature to adjust to its morphological setup. The study can provide additional knowledge to the studies involving anomalous channel cut-offs at any part of the world.

\section{Acknowledgements}

The paper is the outcome of an annual departmental project of Savitribai Phule Pune University, Pune, India. Author would also like to acknowledge the help from many students of the department during the fieldwork. They are Devidas Tambe, Madhuri
Nalawade, Debasree Sinha, Mahesh Jagdale, Yogesh Raskar and Vikas Nagare. The Department of Geography, SPPU is gratefully acknowledged for providing the fieldwork infrastructures and giving me complete access to all the laboratory facilities to conduct the study.

\section{References}

Asahi, K. - Shimizu, Y. - Nelson, J. - Parker, G. (2013): Numerical simulation of river meandering with self-evolving banks. Journal of Geophysical Research: Earth Surface 118: 2208-2229.

Bogoni, M. - Putti, M. - Lanzoni, S. (2017): Modeling meander morphodynamics over self-formed heterogeneous floodplains. Water Resources Research 53: 5137-5157

Davis, W. M. (1913): Meandering valleys and underfit rivers. Annals of the Association of American Geographers 3: 3-28.

Dury, G.H. (1960): Misfit streams: problems in interpretation, discharge and distribution. Geographical Review 50: 219-242.

Finotello, A. - D’Alpaos, A. - Bogoni, M. - Ghinassi, M. Lanzoni, S. (2020): Remotely-sensed planform morphologies reveal fluvial and tidal nature of meandering channels, Scientific Report 10: 54.

Folk, R.L. - Ward, W.C. (1957): Brazos River bar: a study in the significance of grain size parameters, Journal of Sedimentary Petrology 27: 3-26.

Güneralp, I. - Marston, R. (2012): Process-form linkages in meander morphodynamics, Progress in Physical Geography 36 (6): 718746

Hooke, J. (2003): River meander behavior and instability of framework for Analysis: Transactions, Institute of British Geographers 28: 238-253.

Ielpi, A.- Lapôtre, M.G.A. (2020): A tenfold slowdown in river meander migration driven by plant life. Nature Geoscience 13, 82-86.

Joshi, V.U - Kale V.S. (2005): Anomalous sinuosity in an ephemeral stream, Deccan Trap Region, India: The role of local base level: Transactions, Japanese Geomorphologial Union 26(1): 1-12.

Kailasam, L.N. - Murthy, B.G. - Chayanulu, A.Y.S.R. (1972): Regional gravity studies of the Deccan trap areas of peninsular India. Current Science, 42: 403- 407

Kale, V.S. - Rajaguru, S.N. (1986): A parametric approach to terrain analysis and geomorphic regionalization of Pravara River Basin (Maharashtra), Journal of Geological. Society of 
India 27(4): 369-378

Leopold, L.B. - Wolman, M.G. (1957): River channel pattern: braided, meandering and straight. physiographic and hydraulic studies of rivers. U.S. Geological Survey Professional Paper. 282B: 85

Lewin, J. - Brewer, P. (2001): Predicting channel patterns. Geomorphology 40: 329-339

Luchi, R. - Zolezzi, G. - Tubino, M. (2011): Bend theory of river meanders with spatial width variations. Journal of Fluid Mechanics 681: $311-339$

Miall, A.D. (1977): A review of the braided-river deposional environment Earth Science Review, 13: 1-62.

Miall, A.D. (1996): The Geology of Fluvial Deposits: Sedimentary facies, basin analysis and petroleum geology, Springer-Verlag, Berlin.

Matsubara, Y. - Howard, A.D. - Burr, D. M. - Williams, R. M. E. - Dietrich, W. E. - Moore, J. M. (2015): River meandering on Earth and Mars: A comparative study of Aeolis Dorsa meanders, Mars and possible terrestrial analogs of the Usuktuk River, AK, and the Quinn River, NV. Geomorphology 240: 102-120

Nagata, T. - Watanabe, Y. Yasuda, H and Ito, A. (2014): Development of a meandering channel caused by the plane shape of the river bank. Earth Surface Dynamics. 2: 255-270

Schumm, S.A. - Khan, H.R. (1972): Experimental study of channel patterns. Bulletin of Geological Society of America 83: 1755-1770
Silva, D. F. (2006): 14th IAHR Arthur Thomas Ippen Award Lecture, XXXI IAHR Congress, Seoul, South Korea, September 2005, on why and how do rivers meander, Journal of Hydraulic Research 44(5): 579-590

Słowik, M. (2016): The influence of meander bend evolution on the formation of multiple cutoffs: Findings inferred from floodplain architecture and bend geometry. Earth Surface Process and Landforms 41(5): 626-641

Smith, C.E. (1998): Modeling high sinuosity meanders in a small flume. Geomorphology 25: 19-30.

Sylvester, Z. - Durkin, P. R - Covault, J. A. (2019): High curvatures drive river meandering, Geology 47(3): 263-266

Thompson, M. D. (2003): A Geomorphic Explanation for Meander Cutoff Following Channel Relocation of a Coarse-Bedded River. Environmental Management 31(3): 385-400.

Van den Berg, J.H. (1995): Prediction of alluvial channel pattern of perennial rivers, Geomorphology 12: 259-279.

Williams, G.P. (1983): Paleohydrology methods and some examples from Swedish fluvial environment. I. Cobble and boulder deposites. Geografiska Annaler 65A(3-4): 227-243

Yong, N. S - Mohamad, I. N. - Lee, W. K. (2018): Experimental study on river meander planform pattern. International Journal of Engineer and Technology 7 (3,11): 214-217

Zingg, T. (1935): Beitrage zur Schotteranalyse. Min. Petrog. Mitt. Schweiz. 15: 39-140. 